\title{
Pitaya (Hylocereus undatus) initial growth in function to NPK fertilization
}

Ana Flávia Matias Gonçalves ${ }^{1}$

Sheila Isabel do Carmo Pinto²

Ricardo Monteiro Corrêa ${ }^{3}$

\section{Abstract}

Pitaya is considered a very promising cactus fruit, however, there is a lack of studies that support the definition of more suitable production systems. Thus, the objective of this work was to evaluate the effect of NPK mineral fertilization on pitaya initial growth, aiming the definition of nutritional and fertilization management appropriate to the agricultural exploitation of the crop. The assay was conducted in the greenhouse of the Biotechnology Laboratory. The propagating part of pitaya is its stem known as cladode. The cladodes were planted in pots of $8.0 \mathrm{dm}^{3}$, filled with substrate based on soil from termites. The donor matrices of vegetative material were young specimens of white-fleshed pitaya (Hylocereus undatus). 72 cuttings of $30.0 \mathrm{~cm}$ in length were used. The experimental design was in randomized blocks with 9 treatments (NPK doses) and 4 replications, totalizing 36 experimental plots. Each experimental plot was composed of 2 cuttings. Number of cladodes, sum of cladodes length, fresh cladodes mass, dry cladodes mass, root system length, root system fresh mass and root system dry mass were evaluated at 160 days after planting the morphological characters. The results of the variables were submitted to the analysis of variance and the means grouped by the Scott-Knott test at $5 \%$ of probability. NPK fertilization affected the initial growth of the aerial part and the root system of pitaya. The greatest development of pitaya was provided by $450.0 \mathrm{mg} \mathrm{dm}^{-3}$ of $\mathrm{N}$, $250.0 \mathrm{mg} \mathrm{dm}^{-3}$ of $\mathrm{P}$ and $250.0 \mathrm{mg} \mathrm{dm}^{-3}$ of $\mathrm{K}$.

Keywords: Cactus. Nitrogen. Phosphorus. Potassium.

\section{Introduction}

In recent years, several cactus species have stood out for their potential as a source of food, among them, it highlights the fruit, creeper cactus, most cultivated in the world, native to the tropical forests of Mexico and Central and South America, called pitaya (Hylocereus undatus) (COSTA, 2012).

In Brazil, pitaya is considered a new and promising fruit in the market. It may be a potentially viable alternative to soils little fertilized, making their cultivation promising from an agronomic view. Their characteristics have aroused interest in producers for their wide acceptance in consumer markets. Although it is considered an exotic fruit, native pitaya species are found in the Cerrado of the genus Selenicereus and Hylocereus, popularly known as pitaya-of-cerrado or "tasty" (JUNQUEIRA et al., 2002).

1 Instituto Federal de Educação, Ciência e Tecnologia de Minas Gerais IFMG - Campus Bambuí, discente do curso de Agronomia.ana. flaviagoncalves@hotmail.com. Fazenda Varginha, Rodovia Bambuí-Medeiros, Km 5, Bambuí (MG)

2 IFMG - Campus Bambuí, docente pesquisador. sheila.isabel@ifmg.edu.br.

3 IFMG - Campus Bambuí, docente pesquisador. ricardo.correa@ifmg.edu.br. 
Considering the growth demand for exotic fruits, the scarcity of their availability for the consumer market, the high commercial potential for the consumer market, the high commercial potential for domestic and foreign markets and the small number of studies and publications about the cultivation, there is a need of intensification of researches, mainly aiming at obtaining basic information about the crop, which can be used by the producers.

The determination of adequate doses of NPK to the pitaya initial development is very relevant to subsidize production systems more suitable for the economic exploitation of this crop in Brazil. Lone (2013) points out that due to the increase of pitaya consumption in recent years, there is a need for intensification of researches, mainly aiming to obtain basic nutritional information about the crop. There are few articles in the literature about the effect of phosphorus (MOREIRA et al., 2016), phosphorus and zinc (CORRÊA et al., 2014; ALMEIDA et al., 2016), nitrogen and potassium (ALMEIDA et al., 2014; 2016) and potassium and calcium (CAJAZEIRA et al., 2018) on the pitaya initial development. Therefore, given the importance of a balanced fertilization, especially with nitrogen, phosphorus and potassium, it is essential to conduct research about the effect of these primary macronutrients on pitaya development.

In this context, the objective of the present work was to evaluate the effect of NPK mineral fertilization on the pitaya initial growth, aiming the definition of fertilization management appropriate to the agricultural exploitation of this crop.

\section{Material and methods}

The research was conducted at the premises of the Biotechnology Laboratory (Labiotec), which belongs to the Department of Agrarian Sciences of the Federal Institute of Education, Science and Technology of Minas Gerais-Campus Bambuí.

The planting of the pitaya propagating parts was carried out in pots with capacity of $8.0 \mathrm{dm}^{3}$, filled with substrate based on soil from termites.

The material used was prepared according to Sousa (2009). Only the central and darkened part of the termite nest was used, which was dried and disinfected under black polyethylene tarpaulin exposed to sun until it had little moisture. Subsequently, the material was manually crushed and homogenized.

The donor matrices of vegetative material were young specimens of white pitaya (Hylocereus undatus) cultivated in the greenhouse of the Biotechnology Laboratory. In the early morning of October 16, 2017, 72 cuttings (apical or median) of $30.0 \mathrm{~cm}$ of length, from the main cladode of the plants (main stem) were taken, and then planted in the pots prepared the previous day.

The experiment was conducted under randomized blocks with 9 treatments (NPK doses) and 4 replications, totalizing 36 experimental plots. Each experimental plot was composed with 2 cuttings. Therefore, 72 pots of $8.0 \mathrm{dm}^{3}$ were used with one cutting each.

The NPK doses used in the different treatments are presented in Table 1. 
Table 1 - Doses of N, P and K used in pitaya (Hylocereus undatus) cultivation

\begin{tabular}{cccc}
\hline \multirow{2}{*}{ Treatment } & \multicolumn{3}{c}{ Doses $\left(\mathrm{mg} \mathrm{dm}^{-3}\right)$} \\
\cline { 2 - 4 } & $\mathbf{N}$ & $\mathbf{P}$ & $\mathbf{K}$ \\
\hline 1 & 0 & 0 & 0 \\
3 & 300 & 150 & 150 \\
4 & 300 & 150 & 250 \\
5 & 300 & 250 & 150 \\
6 & 300 & 250 & 250 \\
7 & 450 & 150 & 150 \\
8 & 450 & 150 & 250 \\
9 & 450 & 250 & 150 \\
\hline
\end{tabular}

Source: Elaborated by the authors (2018).

The fertilizers used as source of N,P and K were, respectively: ammonium sulfate ( $18 \%$ of $N$ ), simple superphosphate ( $18 \%$ of $\mathrm{P}$ ) and potassium chloride ( $58 \%$ of $\mathrm{K}$ ). For basic fertilization (same for all pots), $25.0 \mathrm{mg} \mathrm{dm}^{-3}$ (applied $0.2 \mathrm{~g}$ per pot) of FTE BR-12 were used. With the exception of FTE BR-12, which was applied at once when filling the pots, the other fertilizers were applied divided into two applications: half in the pot filling, performed on October 16, 2017, and the other half, 50 days after filling the pots on December, 6, 2017.

Throughout the experiment conduction, manual weeding of all pots was performed when necessary. Irrigation was performed manually, each pot received about $50.0 \mathrm{ml}$ of water, with a 7-day watering shift. Plant staking was performed on December, 18, 2017, utilizing bamboo stakes with sisal rope to provide vertical support to the pitaya aerial part.

The evaluation was performed on March 26 and 27, 2018, that is, 160 days after the pitaya cuttings planting. All samples were evaluated because no damage occurred to the 72 repetitions. The morphological traits of the aerial part (number of cladodes (NC), sum of cladodes length (SCL), fresh cladodes mass (FCM) and dry cladodes mass (DCM) and of the root system (root system length (RSL), root system fresh mass (RSFM) and root system dry mass (RSDM), as well as the relation between dry cladodes mass and root system dry mass (RCRS)).

All cladodes were counted (NC) and the sum of their length (SCL) was inferred by measuring through a ruler graduated in $\mathrm{cm}$. The substrate of each sample was removed by mild water jet washing in order to avoid damaging the roots. The samples were taken to the Biotechnology Laboratory to measure the root system length (RSL). To determine the fresh cladodes mass (FCM) and the root system (RSFM), the cladodes were separated from the roots and they were weighed separately on an analytical scale. Subsequently, they were placed separately in kraft paper envelopes, identified with the corresponding treatment and, subsequently, the samples were dried in laboratory oven at $65^{\circ} \mathrm{C}$ for 72 hours to determine the dry cladodes mass (DCM) and the root system (RSDM) by weighing them on an analytical scale. With the dry weight of these samples, it was obtained the relation between the dry cladodes mass and the root system dry mass (RCRS).

The obtained data from the morphological characters of the aerial part and the root system of the pitayas were submitted to variance analysis and the means grouped by the Scott-Knott test at $5 \%$ of probability using the Sisvar software (FERREIRA, 2011). 


\section{Results and discussion}

It was verified an effect ( $p<0.05$ ) of NPK fertilization on the initial growth of the white pitaya for most of the morphological characteristics analyzed. Effects of the NPK mineral fertilization doses on all pitaya aerial morphological variables $(p<0.05)$ were observed $(T A B L E 2)$.

Table 2 - Evaluation of morphological characteristics of the aerial part (cladodes) of the pitaya (Hylocereus undatus) as a function of different doses of NPK mineral fertilizer.

\begin{tabular}{ccccc}
\hline \multicolumn{5}{c}{ Variables } \\
\hline Treatments & NC & SCL & FCM & DCM \\
\hline T 1 & $2.6 \mathrm{~b}$ & $150.1 \mathrm{~b}$ & $333.6 \mathrm{c}$ & $34.5 \mathrm{~b}$ \\
T 2 & $2.9 \mathrm{~b}$ & $175.9 \mathrm{~b}$ & $330.9 \mathrm{c}$ & $33.5 \mathrm{~b}$ \\
T 3 & $2.6 \mathrm{~b}$ & $187.1 \mathrm{~b}$ & $382.8 \mathrm{c}$ & $34.7 \mathrm{~b}$ \\
T 4 & $2.8 \mathrm{~b}$ & $185.0 \mathrm{~b}$ & $265.0 \mathrm{c}$ & $38.1 \mathrm{~b}$ \\
T 5 & $2.8 \mathrm{~b}$ & $182.9 \mathrm{~b}$ & $379.4 \mathrm{c}$ & $46.6 \mathrm{a}$ \\
T 6 & $2.8 \mathrm{~b}$ & $209.2 \mathrm{a}$ & $427.6 \mathrm{~b}$ & $41.5 \mathrm{~b}$ \\
T 7 & $4.0 \mathrm{a}$ & $261.0 \mathrm{a}$ & $416.6 \mathrm{~b}$ & $44.8 \mathrm{a}$ \\
T 8 & $3.6 \mathrm{a}$ & $233.4 \mathrm{a}$ & $445.2 \mathrm{~b}$ & $41.4 \mathrm{~b}$ \\
T 9 & $3.5 \mathrm{a}$ & $236.5 \mathrm{a}$ & $536.2 \mathrm{a}$ & $55.6 \mathrm{a}$ \\
CV (\%) & 26.1 & 26.2 & 23.9 & 24.9 \\
\hline
\end{tabular}

Means followed by the same letter for each variable do not differ from each other by the Scott-Knott test at $5 \%$ of probability. NC: number of cladodes; SCL: sum of cladodes length; FCM: fresh cladodes mass; DCM: dry cladodes mass. CV: coefficient of variation.

Source: Elaborated by the authors (2018).

The number of cladodes (NC) ranged from 2.6 to 4.0 units. Pitaya cuttings that received higher $\mathrm{N}$ dose associated to higher doses of $\mathrm{P}$ and/or $\mathrm{K}$ (treatments 7, 8 and 9) presented higher cladode numbers (NC) (TABLE 2). However, the application of high $\mathrm{N}$ dosage associated to lower $\mathrm{P}$ and $\mathrm{K}$ doses (treatment 6 ) was not able to maintain a satisfactory cladode emission from the pitaya cuttings.

The total length of the cladodes (SCL) ranged from 150.0 to $261.0 \mathrm{~cm}$, higher values than those obtained by Almeida et al. (2014) and Corrêa et al. (2014) in pitaya plants. SCL was higher in plants that received the highest $\mathrm{N}$ dose, regardless of the $\mathrm{P}$ or $\mathrm{K}$ dose (treatment $6,7,8$ and 9) (TABLE 2).

Fresh cladodes mass (FCM) was higher in pitaya plants fertilized with the highest dose of NPK (Treatment 9) (TABLE 2). Therefore, plants tend to increase mass production when nitrogen, phosphorus and potassium levels are increased, consequently, the variation in nutrient distribution influences the developmental characteristics of cladodes.

Pitaya cuttings with higher dry mass production of cladodes (DCM) were the ones that received the highest $\mathrm{K}$ dosage, especially when associated with higher $\mathrm{N}$ or $\mathrm{P}$ dose (treatments 5,7 and 9) (TABLE 2). Almeida et al. (2014) observed that low $\mathrm{N}$ availability has a limiting effect on DCM increase, and $\mathrm{K}$ has more evident effect on the increased efficiency $\mathrm{N}$ use by pitaya. Therefore, low doses of $\mathrm{N}$ reduce the dry mass production by the cladodes, however the application of adequate $\mathrm{N}$ dose must be associated with the sufficient $\mathrm{K}$ dose since it increases the utilization of $\mathrm{N}$ in pitaya metabolism. 
These authors obtained an increase of up to eight times in DCM, expressing the importance of rational application of $\mathrm{N}$ and $\mathrm{K}$ on the pitaya initial growth.

According to Sarment et al. (2008), when N supply is performed under conditions of low K availability, there is a low efficiency of $\mathrm{N}$ use by the plant. Almeida et al. (2016), when evaluating the nutritional status of pitaya plants submitted to different doses of $\mathrm{N}$ and $\mathrm{K}$, observed the high demand of this species by K, demanding around twice more K than N. Fernandes et al. (2018) verified the importance of $\mathrm{K}$ also on the increase of production and quality of pitaya fruits.

DCM ranged from $33.5 \mathrm{~g}$ to $55.6 \mathrm{~g}$, while FCM ranged from 265.0 to $536.2 \mathrm{~g}$. Relating both results, it was estimated that around 87.4 to $89.6 \%$ of the plant tissue consisted of water. These results corroborated the moisture content described by Goldstein et al. (1991) for succulent cacti and those verified by Almeida et al. (2014) and Corrêa et al. (2014) in pitaya plants.

NPK application should be done in an amount that favors adequate availability to the plants. In the present work it was verified that treatment with the highest doses of $\mathrm{N}\left(450.0 \mathrm{mg} \mathrm{dm}^{-3}\right), \mathrm{P}(250.0$ $\mathrm{mg} \mathrm{dm}^{-3}$ of $\mathrm{P}$ ) and of $\mathrm{K}\left(250.0 \mathrm{mg} \mathrm{dm}^{-3}\right.$ of $\mathrm{K}$ ) contributed to accelerate initial aerial part growth of the white pitaya. Significant effects on these characteristics could be expected, because nitrogen acts as a cell division and stretching stimulator, which would promote direct effects on the production of more vigorous cladodes (MALAVOLTA, 2006), and as a result of phosphorus favoring plant development, acting as a nutrient that stimulates phytomass production (MOREIRA, 2012), as well as potassium that promotes stem diameter increase (INTA, 2002). $\mathrm{K}$ is one the most required elements, especially for performing the functions of carbohydrate translocation and stomatal opening and closing regulation for water use (MARSCHNER, 2005).

The effect of NPK fertilization on the early growth of white pitaya was verified for the morphological characteristics of the root system: root system length (RSL), root system dry mass (RSDM) and relation between dry cladodes mass and root system dry mass (RCRS) (TABLE 3).

Table 3 - Evaluation of the morphological characteristics of pitaya (Hylocereus undatus) root system as a function of different doses of NPK mineral fertilizer

\begin{tabular}{ccccc}
\hline \multirow{2}{*}{ Treatments } & \multicolumn{5}{c}{ Variables } \\
\cline { 2 - 5 } & RSL & RSFM & RSDM & RCRS \\
\hline T 1 & $29.1 \mathrm{~b}$ & $11.3 \mathrm{a}$ & $3.57 \mathrm{a}$ & $11.3 \mathrm{c}$ \\
T 2 & $37.5 \mathrm{a}$ & $11.2 \mathrm{a}$ & $3.06 \mathrm{a}$ & $11.2 \mathrm{c}$ \\
T 3 & $40.1 \mathrm{a}$ & $10.4 \mathrm{a}$ & $3.35 \mathrm{a}$ & $9.95 \mathrm{c}$ \\
T 4 & $38.0 \mathrm{a}$ & $11.2 \mathrm{a}$ & $2.35 \mathrm{~b}$ & $17.5 \mathrm{~b}$ \\
T 5 & $42.1 \mathrm{a}$ & $11.0 \mathrm{a}$ & $2.70 \mathrm{~b}$ & $17.6 \mathrm{~b}$ \\
T 6 & $34.3 \mathrm{~b}$ & $10.9 \mathrm{a}$ & $2.43 \mathrm{~b}$ & $19.0 \mathrm{~b}$ \\
T 7 & $33.5 \mathrm{~b}$ & $10.3 \mathrm{a}$ & $2.82 \mathrm{~b}$ & $21.8 \mathrm{a}$ \\
T 8 & $34.1 \mathrm{~b}$ & $9.9 \mathrm{a}$ & $1.93 \mathrm{~b}$ & $21.4 \mathrm{a}$ \\
T 9 & $33.5 \mathrm{~b}$ & $13.7 \mathrm{a}$ & $2.81 \mathrm{~b}$ & $23.0 \mathrm{a}$ \\
CV (\%) & 12.9 & 28.1 & 33.2 & 27.7
\end{tabular}

Means followed by the same letter for each variable do not differ from each other by the Scott-Knott test at $5 \%$ of probability. RSL: root system length; RSFM: root system fresh mass; RSDM: root system dry mass. RCSR: relation between dry cladodes mass and root system dry mass. CV: coefficient of variation.

Source: Elaborated by the authors (2018). 
The length of the root system ranged from 29.0 to $42.0 \mathrm{~cm}$, values close to those presented by Corrêa et al. (2014) in pitaya plants. The treatments that provided the longest root system length (RSL) were treatments 2, 3, 4, and 5, ranging from 37.5 to $42.1 \mathrm{~cm}$ with the lowest nitrogen dose (300.0 mg dm$~^{-3}$ ) (TABLE 3). The lowest values were found with the use of $450.0 \mathrm{mg} \mathrm{dm}^{-3}$ of $\mathrm{N}$ (highest dose) and treatment 1 without nitrogen addition. Thus, it was observed that the use of high doses of $\mathrm{N}$ caused reduction of root system growth, which is in line to the studies by Silva (2014). Almeida et al. (2014) also observed that the use of low doses of $\mathrm{N}$ reduced the vertical growth of the root system of pitaya plants.

The root system dry mass (RSDM) variable was benefited with the lower $\mathrm{N}$ dose associated with low $\mathrm{P}$ doses. Treatments 1,2 , and 3 were statistically superior to other treatments presenting higher dry mass production by the root system (TABLE 3). Almeida et al. (2014) also found that $N$ deficiency in the soil culminated in an increase in mass of pitaya root system. Corrêa et al. (2014) mention that the high dose application of $\mathrm{P}\left(300 \mathrm{mg} \mathrm{dm}^{-3}\right)$ stimulated pitaya vegetative growth over the root system. These results corroborate those presented by Almeida Júnior et al. (2009), who found that under conditions of high $\mathrm{P}$ availability in the soil plants have the possibility of investing a greater portion of energy on the increment of the aerial part. However, Corrêa (2004) states that adequate $\mathrm{P}$ supply can induce root system growth, since it is essential for its formation.

Pitaya cuttings that received the highest dose of $\mathrm{N}$ associated to higher doses of $\mathrm{P}$ and/or $\mathrm{K}$ (Treatments 7, 8 and 9) presented higher relation between dry cladodes mass and root system dry mass (RCRS) (TABLE 3). Silva (2014) emphasizes that the excess of $N$ in the soil can increase the relation aerial part/root, reducing the longitudinal growth of the root system and, consequently, reducing the plants resistance to dry periods. Almeida et al. (2014) also observed that the application of increasing doses of $\mathrm{N}$ and $\mathrm{K}$ resulted in adverse effects on in the relation aerial part/root.

\section{Conclusions}

NPK fertilization affected the initial growth of the aerial part and the root system of the pitaya. The greatest development of pitaya was provided by $450.0 \mathrm{mg} \mathrm{dm}^{-3}$ of $\mathrm{N}, 250.0 \mathrm{mg} \mathrm{dm}^{-3}$ of $\mathrm{P}$ and $250.0 \mathrm{mg} \mathrm{dm}^{-3}$ of $\mathrm{K}$.

\section{Crescimento inicial da pitaya (Hylocereus undatus) em função da adubação com NPK}

\section{Resumo}

A Pitaya é considerada uma cactácea frutífera muito promissora, no entanto, carente de estudos preliminares que subsidiem a definição de sistemas de produção mais adequados. Assim, o objetivo deste trabalho foi avaliar o efeito da adubação mineral com NPK sobre o crescimento inicial da pitaya, visando à definição de manejos de nutrição e fertilização adequados à exploração agrícola da cultura. O ensaio foi conduzido na estufa do Laboratório de Biotecnologia. A parte propagativa da pitaya é o seu caule conhecido como cladódio. O plantio dos cladódios foi realizado em vasos de $8,0 \mathrm{dm}^{3}$, preenchidos com substrato à base de terra de cupim. As matrizes doadoras de material vegetativo foram exemplares jovens de pitaya vermelha da polpa branca (Hylocereus undatus). Fo- 
ram utilizadas 72 estacas de $30,0 \mathrm{~cm}$ de comprimento. 0 delineamento experimental utilizado foi em blocos casualizados com 9 tratamentos (doses de NPK) e 4 repetições, totalizando 36 parcelas experimentais. Cada parcela experimental foi composta de 2 estacas. Aos 160 dias após o plantio foram avaliados os caracteres morfológicos: número de cladódios, somatório do comprimento dos cladódios, massa fresca dos cladódios, massa seca dos cladódios, comprimento do sistema radicular, massa fresca do sistema radicular e massa seca do sistema radicular. Os resultados das variáveis foram submetidos à análise de variância e as médias agrupadas pelo Teste de Scott-Knott a 5\% de probabilidade. A adubação com NPK afetou o crescimento inicial da parte aérea e do sistema radicu-

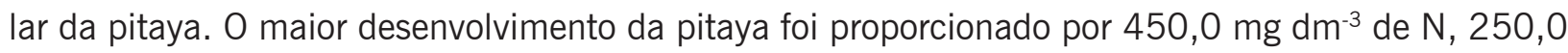
$\mathrm{mg} \mathrm{dm^{-3 }}$ de $\mathrm{P}$ e 250,0 $\mathrm{mg} \mathrm{dm}^{-3}$ de $\mathrm{K}$.

Palavras-chave: Cactácea. Nitrogênio. Fósforo. Potássio.

\section{Referências}

AlMEIDA, E. I. B.; CORRÊA, M. C. M.; CRISÓstomo, L. A.; ARAÚJO, N. A.; SILVA, J. C. V. Nitrogênio e potássio no crescimento de mudas de pitaia [Hylocereus undatus (Haw.) Britton \& Rose]. Revista Brasileira de Fruticultura, Jaboticabal, v. 36, n. 4, p. 1018-1027, dez. 2014.

ALMEIDA, E. I. B.; DEUS, J. A. L.; CORRÊA, M. C. M.; CRISOSTOMO, L. A.; NEVES, J. C. L. Linha de fronteira e chance matemática na determinação do estado nutricional de pitaia. Revista Ciência Agronômica, Fortaleza, v. 47, n. 4, p. 744-754, out-dez, 2016.

ALMEIDA-JÚNIOR, A. B.; OLIVEIRA, F. A.; MEDEIROS, J. F.; OLIVEIRA, M. K.T. Efeitos de doses de fósforo no desenvolvimento inicial da mamoneira. Revista Caatinga, Mossoró, v. 22, p. 217-221, 2009.

CAJAZEIRA, J. P.; CORRÊA, M. C. M.; ALMEIDA, E. I. B.; QUEIROZ, R. F.; MESQUITA, R. O. Growth and gas exchange in white pitaya under different concentrations of potassium and calcium. Revista Ciência Agronômica, Fortaleza, v. 49, n. 1, p. 112-121, mar. 2018.

CORRÊA, M. C. M.; ALMEIDA, E. I. B.; MARQUES, V. B.; SILVA, J. C. V.; AQUINO, B. F. Crescimento inicial de pitaia em função de combinações de doses de fósforo-zinco. Revista Brasileira de Fruticultura, Jaboticabal, v. 36, n. 1, p. 261-270, 2014.

CORRÊA, J. L.; MAUAD, M.; ROSOLEM, C. A. Fósforo no solo e desenvolvimento de soja, influenciados pela adubação fosfatada e cobertura vegetal. Pesquisa Agropecuária Brasileira, Brasília, v. 39, p. 1231-1237, 2004.

COSTA, A. C. Adubação orgânica e ensacamento de frutas na produção da pitaia vermelha. 2012. 69 p. Tese (Doutorado em Produção Vegetal) - Universidade Federal de Lavras, Lavras. 
FERNANDES, D. R.; MOREIRA, R. A.; CRUZ, M. C. M.; RABELO, J. M.; OLIVEIRA, J. Improvement of production and fruit quality of pitayas with potassium fertilization. Acta Scientiarum Agronomy, Maringá, v. 40, e35290, 2018.

FERREIRA, D. F. Sisvar: a computer statistical analysis system. Ciência e Agrotecnologia, Lavras, v. 35, n. 6, p. 1039-1042, dez. 2011.

GOLDSTEIN, G.; ORTEGA, J. K. E.; NERD, A.; NOBEL, P. S. Patterns of water potential components for the crassulacean acid metabolism plant Opuntia ficus-indica when well-watered or droughted. Plant Physiology, New York, v. 95, p. 274-280, 1991.

INTA. Instituto Nicaraguense de Tecnología Agropecuária. Guía tecnológica del cultivo de la pitahaya. 2002.

JUNQUEIRA, K. P.; JUNQUEIRA, N. T. V.; RAMOS, J. D.; PEREIRA, A. V. Informações preliminares sobre uma espécie de Pitaya do Cerrado. Planaltina: EMBRAPA Cerrados, 2002. 18 p.

LONE, A. B. Substratos, ácido indolbutírico e períodos do ano na propagação de pitaya por estaquia. 2013, 98p. Tese (Doutorado em Agronomia) - Universidade Estadual de Londrina, Londrina.

MALAVOlTA, E. Manual de nutrição mineral de plantas. São Paulo: Editora Agronômica Ceres, 2006.

MARSCHNER, H. Mineral nutrition of higher plants. 2ed. Orlando: Academic Press, 2005.

MOREIRA, R. A.; RAMOS, D. R.; SILVA, F. O. R.; MARQUES, V. B. Cultivo da pitaya: implantação. Boletim Técnico - n. ${ }^{\circ}$ 92, Lavras/MG, 2012.

MOREIRA, R. A. M.; CRUZ, M. C. M.; FERNADES, D. R.; SILVA, E. B.; OLIVEIRA, J. Nutrient accumulation at the initial growth of pitaya plants according to phosphorus fertilization. Pesquisa Agropecuária Tropical, Goiânia, v. 46, n. 3, p. 230-237, set. 2016.

SARMENTO, P.; RODRIGUES, L. R. A.; CRUZ, M. C. P. da; LUGÃO, S. M. B.; CAMPOS, F. P. de; CENTURION, J. F.; FERREIRA, M. E. Atributos químicos e físicos de um Argissolo cultivado com Panicum maximum Jacq. cv.IPR-86 Milênio, sob lotação rotacionada e adubado com nitrogênio. Revista Brasileira de Ciência do Solo, Viçosa, MG, v. 32, n. 1, p. 183-193. 2008.

SILVA, A. C. C. Melhoramento e produção de mudas de Pitaya. Jaboticabal, 2014, 132 p.

SOUSA, G. G. Absorção de boro e crescimento do maracujazeiro adubado com boro e material de cupinzeiro. 2009, 41 p. Dissertação (Mestre em produção vegetal). Universidade Federal da Grande Dourados, Dourados, MS.

Received: August 2, 2018

Accepted in: February 6, 2019 